\title{
Response of Cireundeu Indigenous Community to Modernization and Islamic Da'wa
}

\author{
Yusuf Zainal Abidin ${ }^{1 *}$ \\ ${ }^{1}$ UIN Sunan Gunung Djati, Bandung, Indonesia \\ *yusufzainalabidin@uinsgd.ac.id
}

\begin{abstract}
This article describes the dynamics of the indigenous people of Cireundeu in Cimabi with their specific systems in responding to the current modernization and Islamic da'wa activities. Using a qualitative approach, this article argues that the encounter of their traditions with modernization and Islamic da'wa activities which are new traditions, has made indigenous peoples syncretize through parochalization and universalization. Parochialization is carried out by adjusting outside traditional values through their symbols, while universalization is carried out by promoting their local values or practices such as food security into a broader norm. However, interactions with various other traditions have shown continuity in customary preservation and at the same time have shown discontinuity in symbolic matters, their norms, and practices as indigenous people.
\end{abstract}

Keywords: indigenous people; local religion; parochialization; universalization.

\begin{abstract}
ABSTRAK
Artikel ini menguraikan tentang dinamika masyarakat adat Cireundeu di Cimahi dengan berbagai sistem spesifik yang dimilikinya dalam merespon arus modernisasi dan aktivitas dakwah Islam. Dengan menggunakan pendekatan kualitatif, artikel ini berargumen bahwa perjumpaan tradisi mereka dengan modernisasi dan aktivitas dakwah Islam yang merupakan tradisi-tradisi baru telah membuat masyarakat adat melakukan sinkretitasi melalui parokialisasi dan universalisasi. Parokialisasi dilakukan dengan penyesuaian nilai-nilai tradisi luar melalui simbol-simbol mereka dan universalisasi dilakukan dengan mempromosikan nilai-nilai atau praktik-praktik lokal mereka seperti ketahanan pangan menjadi norma yang lebih luas. Namun demikian, interaksi dengan berbagai tradisi lain ini telah memperlihatkan kontinuitas dalam dalam pelestarian adat dan pada saat yang sama telah pula mempelihatkan gejala diskontinuitas pada hal-hal yang bersifat simbolik, norma dan praktik mereka sebagai masyarakat adat. Kata kunci: masyarakat adat; agama lokal; parokialisasi; universalisasi.
\end{abstract}

Received: Januari 2021. Accepted: Maret 2021. Published: Juni 2021. 


\section{INTRODUCTION}

Kampung Cireundeu is a traditional village in West Java that has been administratively a part of Cimahi City since June 2001 following the change in the status of Cimahi City, which was previously an Administrative City. This village is inhabited by around 700 family heads, some of whom are indigenous people who inhabit an area of about 400 hectares. Geographically, Cireundeu Village includes Leuwigajah Village, Cimahi Tengah District. They are spread across $5 \mathrm{RT}$ areas, and the majority of traditional adherents are concentrated in RT 02 and 03 areas.

These adat adherents are led by traditional leaders, namely (1) Abah Emen Sunarya (main leader); (2) Abah Widia (ais pangampib: internal affairs); and (3) Abah Asep (panitrén: external affairs). Their belief is believed to have originated from the Madrais belief, a teaching brought by Madrais Pangeran Ali Basyah Kusumah, who came from Cigugur, Kuningan and called Pangeran Sepuh or Pangeran Madrais. According to Abah Emen, there is no formal designation for the beliefs they profess. People may call this as Madraism, Sundanese Islam, Sunda Wiwitan, or Javanese-Sundanese religion. According to him, practice is more important than just a name.

Their main teaching is to preserve ancestral customs by respecting the heritage of beliefs, values, norms and symbols of their parents in life, one of which is manifested by not consuming rice as a main food, but making cassava their main food. They followed the ancestral path of the Sundanese people, not the Sundanese Catholics, Christians, Hindus, Buddhists or Muslims. This path is covered by the belief in life that is "manunggal jeung Nu Kagungan" (compounding with the One Who Has the Supreme). Therefore, it is not surprising that this customary religion does not have formal scriptures like other religions, but only pitutur, or ancestral advice to always uphold the Tri Tangtu, namely ucap (words), tekad (thoughts), and lampah (behavior).

On the other hand, Cimahi is a city with rapid development. It has several factories as well as a city with many pesantren (Islamic boarding schools), especially in the South Cimahi area. Some of these things influence each other, both in the aspect of structure and on the culture of the citizens of this city, including the people of Cireundeu. The flow of modernization and the characteristics of a religious city pinned to Cimahi is reflected in the proliferation of various religious activities, including Catholicism, Christianity, Hinduism, Buddhism, and Confucianism, each of 
which has its own place of worship, religious leaders, worship and religious ceremonies. However, like several other cities in West Java that are predominantly Muslim, the liveliness of religious activities is more visible among Muslims. One of the signs of this is the frequency of da'wa activities, especially in areas with a significant number of pesantren. Da'wa in this context is a variety of things that are done as part of a call for a better life from an Islamic perspective (Millie et al., 2020; Mulkhan, 1996; Sambas, 1995).

The modernization and liveliness of preaching activities in Cimahi are, of course, felt by the indigenous people of Cireundeu, which can be seen from the various physical changes in their daily lives. The impact of modernization can be seen from the increasingly modern models of residential buildings, clothing, agricultural equipment, food technology, electricity, electronic equipment, and education. These indigenous children also take formal education up to the high school level, and some even go to college. Therefore, it is interesting to reveal how the religious behavior of the indigenous people of Cireundeu and how their response to the current of modernization and the da'wa movement that is taking place around them is generally related to the continuity and discontinuity of their customary religions.

However, it is realized that several studies related to the life of the Cireundeu indigenous people have been carried out in a variety of different focuses. Some of these studies include framing the context of Cireundeu Village as a tourism destination (Mulyani \& Wirakusuma, 2016), the culture and food security of the Cireundeu community (Fadhilah, 2014; Putranto \& Taofik, 2014), the creativity of the Cireundeu community in processing cassava peels as an alternative raw material for a cloth color barrier (Fitriani \& Ciptandi, 2017), the strong relationship between the indigenous peoples of Cireundeu and their ancestral values and how they are maintained and transformed (Emilda, 2018; Nurhayanto et al., 2016; Purwasih et al., 2019; Ramadhan, 2016; Sumiati, 2016; Tramontane, 2017).

Meanwhile, more specific studies related to the issue of their beliefs in facing modernization have also been studied in the context of the socialization and enculturation of their teaching traditions in the family environment (Achdiani, 2012) as an effort to defend against the current modernization (Adnan \& Solihin, 2018). Meanwhile, other research related to the context of da'wa is carried out as a framework for analysis of the opportunities and challenges of da'wa in the Cireundeu indigenous 
community along with the problems that arise (Fatimah, 2014; Nurrohman \& Suhendi, 2019), which are generally similar to the practice of da'wa in other indigenous contexts (Enjang, 2019).

The various studies above illustrate that the cultural potential of the Cireundeu indigenous people is so significant and always interesting to learn. In a broader analytical framework, the interaction of the Cireundeu indigenous people with other cultures or life contexts generally leads to a syncretization process described in more detail by Marriott (1955) as the interaction between large traditions and small traditions in two forms; parochialization, namely how the acceptance of outside traditions and universalization, namely how ideas in the tradition are promoted to the outside community. Therefore, this paper examines how parochialization and universalization carried out by the indigenous people of Cireundeu are related to modernization and Islamic da'wa activities around them.

Conceptually, this paper frames the phenomenon of the Cireundeu customary religion as a local religion that they profess which theoretically is often synonymous with animism and magic. The term local religion is used as a substitute for the term 'original religion' which was previously developed in the academic world but has received a lot of criticism because it seems to position other religions to be "false religion" or "not genuine." Meanwhile, the term 'local religion' is chosen because it is very local and different from major religions, which can be termed 'universal religion' (Taum, 1998).

In general, this local religion has a lot to do with animism, which assumes that humans, all living things, and inanimate objects have souls. According to Taylor (cited in Dhavamony, 1995: 66), this animism is the forerunner of modern religion. In practical terms, animism refers to beliefs and practices related to ancestors. The ancestors are felt to be still alive in an effective form so that they can interfere with human life (Dhavamony, 1995: 79). Based on this belief, humans are required to develop the welfare of their ancestors who have died. This is manifested in the ritual practices of making offerings or offerings, ranging from simple forms such as offering the first fruit placed in a forest or in a field, to more complex forms of offering at holy or public places (Dhavamony, 1995: 168). Basically, ritual is an expression that is more logical than just psychological because it shows an order of objected symbols important for togetherness in a religious group (Dhavamony, 1995: 174). This is what then causes worship, in general, to be collective in nature. 
In traditional societies, ritual behaviors can generally be explained by myths. Myths are indeed sacred and always have special importance in society. The characteristic of myth lies in the fact that myth refers to "the events in which humans realize and explain the absolute essence of their existence and at the same time provide unity of meaning for the present, past and future. Myth is said to be a story within the framework of a religious system which in the past or present has been or is currently acting as religious truth. The science of myths or mythology is a way of expressing, presenting "the sacred" through concepts and symbolic language (Daeng, 2000: 44).

Thus, ritual is one of the most practical manifestations of syncretization because it refers to the unification of two or more cultural traditions. Although some scholars distinguish the traditions involved in this syncretization as major and minor, Tambiah (1970) rejects the distinction of the two traditions as an ahistorical artifact of anthropological research because religions such as Hinduism and Buddhism include a selected variable of the text written in different periods of history, although they are often presented as a synchronic totality. This objection can be applied in Asia, but not to Christian studies in Europe, where the main sacred texts and official rites are highly agreed upon by adherents (Stewart, 1991). One cannot easily accuse European Christian anthropologists of concentrating on literature studies and finding only great traditions. In a place marked by the separation of large traditions and minor traditions, Tambiah (1970) proposes a separation between historical and contemporary religion to examine the continuation and transformation between the two.

With this understanding, both the symptoms of modernization and Islamic da'wa activities constitute a flow of external traditions that are considered new in the context of the Cireundeu indigenous people compared to their traditions that they have maintained since the time of their ancestors. However, this new flow of tradition is strong, so the indigenous people of Cireundeu are trying to carry out syncretization efforts to respond to the current changes they are constantly facing.

Therefore, by using a qualitative study, this paper is intended to understand the religious phenomena of the Cireundeu indigenous people based on their point of view and their natural environment concerning the flow of modernization and Islamic da'wa activities around them. The qualitative method is seen as a research procedure that can produce written 
or oral information regarding the response of the Cireundeu community to modernization and the Islamic da'wa movement. Data obtained through observation and in-depth interviews and documentation study. Interviews were conducted with several elders of the Cireundeu indigenous community, Muslim leaders, and the Government of Cimahi. Meanwhile, documentation studies were obtained through reports, research results, and other references related to the lives of the indigenous people of Cireundeu.

In the next stage, data were analyzed in the following manner; data reduction, namely summarizing the data obtained and focused on main matters and related to the problem; data display is done by displaying data by narrating, making models, and so on so that data can be mapped more clearly; and draw conclusions and verification before being presented completely.

\section{RESULTS AND DISCUSSION}

Like other indigenous peoples, the indigenous people in Cireundeu Village face a similar problem, namely modernization which has resulted in the emergence of various threats to the values they have long maintained and inherited from generation to generation. In religious belief practices, indigenous peoples also have local religions that are very specific with practices and rituals that still involve animistic teachings because they believe in the existence and role of ancestors in their daily lives.

Thus, modernization in the context of indigenous peoples actually means not only the physical and cultural changes of the people, which are usually identified as a result of industrialization, but even the teachings they have just become acquainted with, such as Islam, are part of the phenomenon of modernization. This view has become a meeting point for why modernization and Islamic da'wa practices that they have encountered are a kind of challenge to the existence of their cultural values and practices that they have been maintaining for a long time ago.

This section describes the response of the Cireundeu indigenous people to the modernization and practice of Islamic da'wa through syncretization efforts. As previously stated, this is since the modernization and practice of Islamic da'wa is a new, larger and broader tradition. If syncretization is an encounter between large traditions and small traditions, the values and beliefs of the Cireundeu indigenous people are seen as minor traditions because of their local scope. As a response to these new traditional currents, syncretization, as described by Marriott (1955) will be 
described in two contexts, namely the context of parochialization and the context of universalization which as a whole provides a comprehensive picture of the responses they show.

\section{Parochializing Modernity and Islamic Da'wa}

One of the common characteristics of indigenous peoples is a strong authority that customary leaders have. Likewise, the indigenous people in Cireundeu Village are all guided by at least three traditional leaders, namely Abah Emen Sunarya as an elder, Abah Widia as ais pangampih, a figure in charge of internal affairs; and Abah Asep as a panitrén or figure in charge of external affairs. These three figures guide all the indigenous people of Kampung Cireundeu to maintain and preserve their ancestral customs.

The indigenous people of Cireundeu Village believe that life must be based on the principle of birup jeung $N u$ Kagunganana (living with the Supreme Owner of Life). Violating this will result in the emergence of arbitrary behavior, for example, corruption, killing, and destroying nature. Therefore, someone's life must be manifested in manunggal (compound) with the Creator, united but not necessarily in one unit so that each individual has the privilege. The union of humans with the Creator will display noble character and bring humans to safety in the afterlife.

The low character will bring people to harm and harm and lead to evil deeds. This will make humans face various kinds of obstacles to get to the eternal realm. The elders always remind us where humans come from, with the pattern of 'wayang nyaho ka dalangna' (puppets that know who is the mastermind). To achieve a good life, each individual must do aji diri (selfunderstanding) and discover what is hidden. This teaching is called 'papat ka lima pancer', namely the four human senses, namely the eyes, ears, nose, and mouth, until the fifth is the pancer (center) which is capable of seeing oneself.

In carrying out their practice of belief, the indigenous people of Cireundeu do not have a specific holy book to hold on to, but only in the form of pitutur (wisdom) which contain oral advice from elders for all indigenous people to always uphold the Tri Tangtu, namely ucap (words), tekad (thoughts) and lampah (behavior). Therefore, the holy book that they believe in is the heart which they illustrate through the term Kitab alit nu aya dina diri urang' (the little book that exists in humans, means heart). With this belief, humans are expected to have the ability to control themselves.

Indigenous people are always guided by traditional leaders to always 
maintain tetekon (main rules of life) in the form of pikukuh tilu (three principles), namely: (1) inget ka Nu Kagungan (always remember the Owner of Life); (2) ngamumulé lemah cai (respecting the homeland); (3) ngamumulé awak urang (respect and take care of the body). In looking at humans, the customary religion of the people of Cireundeu believes that God created humans to work so that identity will emerge. Humans are created from all the elements of the earth which are then reflected in what they say and the weight of their speech. Humans are seen as a micro realm, a picture of the universe as a macro realm. Life is presenting life by feeling of 'kersana kersaning Gusti' (willing of God). So, if a man does not know himself, he will be arrogant and can further destroy the order of life.

Even though the Cireundeu indigenous people believe that humans must be religious, that does not mean following other teachings. Regarding their response to the dynamics of da'wa practices, almost all indigenous people believe that human safety is not measured by the prayers they perform. Even the indigenous people of Cireundeu see that the Quran is only reading material, so that what is more important is actually the language that comes out of the mouth so that guarding the mouth becomes more important. This is reflected in one of their principles, 'Saur kudu diukur, basa kudu dihampelas,' which means that every word spoken must be considered carefully.

Their belief in indigenous religions has driven them to live in freedom; freedom from lust, freedom from colonials, and even freedom because they let go of their dependence on rice as the main food. The indigenous people of Cireundeu make cassava their main food, which is more highlighted by the outside world because it has implications for their food security mechanism. In fact, this is not merely a tradition but is related to the belief in freedom which is based on the belief about being one with the Most Powerful.

Regarding this, the indigenous community of Kampung Cireundeu has a view;

Saha nu méré kakuatan, Gusti nu ngersakeun, Nu ngayugakeun.

Manusa mah kawasa dikawasakeun, kuat lantaran dikuatkeun.

(Who gives strength, It is the Power who permits, Who Provides)

(Humans have power only when given power, strong because they are given strength)

The nature and spirit of freedom that emerge is a soul that fosters togetherness and unity among indigenous people, which is rooted in the 
character of independence and distinctive character. It is not easily influenced by outside beliefs. Even so, the indigenous community of the Cireundeu people still accepts modernization. According to them, modernization is accepted as a step to 'mïndung ka waktu, mibapa ka zaman' (making time as mothers fathers, means change is permanent), this means that they cannot just be separated from the changes and developments of the times. Therefore, the most important thing is that they still hold to another principle, 'ciri wanci, cara mangsa nu teu kaluar tina tetekon' (even though times change and times change, but they don't go out of the way). Humans have power only if given power, strong because it is given strength).

Indigenous people are very open to modern touches. They have built their homes in a modern building style, as can be found in cities or other settlements. They also wear the same clothes as other community groups and are not fixated on traditional clothing as indigenous peoples in general. In addition, some of the agricultural equipment they use is modern and general in nature. Likewise, the utilization of electricity and electronic equipment for daily use is no longer in question. They also see modern education as something important, and this can be seen from their efforts to send their children to high school, and some even go to college.

Of course, this can be seen from the food technology that is very familiar to the people of Cireundeu. Modernization has helped them to be more creative in conserving the use of cassava as a staple food, and they can even process it into a variety of food products with attractive packaging. This has even led them to become pilot models in the field of food security by the Ministry of Agriculture of the Republic of Indonesia.

In responding to modernization, traditional leaders always remind the indigenous people 'boga ajen inajen, ulab unggut kalinduan, ulah gedag kaanginan, ulab kabawa ku sakaba-kaba' (have strong self-esteem, don't be influenced, don't easily get carried away), but must keep the principle 'silih asab silib asib silib asuh. Silib talingakeun' (improving abilities each other, loving one another and taking care of one another. Caring for one another). Therefore, some of the impacts of modernization such as a free lifestyle and even negative things never happen because they have a sense of shame as adherents of adat.

This also applies to their response to the Islamic da'wa activities they encounter. They found some similarities in the teachings and noble values of Islam, but some of these teachings were later adapted to their traditional 
teachings through various symbols such as religious ceremonies and other symbols. This is done so that Islam as new teaching for them does not distance them from their original culture. Thus in general, the practice of syncretization through parochialization carried out by the indigenous people of Cireundeu towards various new traditions from outside, in this case, modernization and Islamic da'wa by making adjustments so that all these new values do not completely remove the foundations of their local beliefs.

\section{Universalization of Local Values against Modernization and Da'wa}

The local religion of the indigenous people of Cireundeu is more of spiritual teaching because it emphasizes substance rather than religion as a formal institution. This is following what Abah Emen and Abah Widia said: "what is important in religion is practice, not the name," namely by believing in the existence of God as the Supreme Ruler and Owner of Life. However, this indigenous belief is believed to be based on the teachings brought by Madrais Pangeran Ali Basyah Kusumah. The indigenous people of Cireundeu call Madrais the Pangeran Sepuh, who is believed to have come from the Cigugur area, Kuningan.

Madrais, also called Pangeran Madrais or Kiai Madrais, is believed to be a descendant of the Gebang Sultanate, a sultanate in the East Cirebon region. When the Dutch East Indies government attacked this sultanate, Madrais was evacuated to the Cigugur area. The prince, also known as Pangeran Sadewa Alibasa, was raised in the Islamic tradition and grew up as a spiritualist. He once founded a pesantren as a center for teaching Islam. However, he later developed an understanding he drew from the preIslamic traditions of agrarian Sundanese society. He taught the importance of respecting the ways and characteristics of one's own nationality, namely Javanese-Sundanese.

Because of his struggle which had the potential to raise nationalism, Madrais was then exiled to Ternate by the Dutch colonialists and only returned around 1920 to continue to spread his teachings. According to Abah Emen, the beginning of the development of Madraism in Cireundeu began when his grandfather, $\mathrm{H}$. Ali, met with Pangeran Madrais in the 1930s. In 1938, Pangeran Madrais visited Cireundeu and lived there for a long time so that his teachings and thoughts developed into the beliefs of the indigenous people of Cireundeu.

In practical terms, the teachings of the indigenous people of 
Cireundeu are mostly preserved in pitutur (wisdom) and examples of behavior. The elders and traditional leaders have the view that "religion is the work of everyday people." This indicates that their association with teachings and beliefs has manifested itself in all their behavior in their daily life and interactions. This is also reinforced by their frequent study of the history of their ancestors so that indigenous people always remember their identity. The presence and togetherness of the elders in the midst of indigenous people make it very easy for residents to have a dialogue about the meaning of life. They can use every opportunity to increase and confirm the truth of their beliefs. The elders are present as the physical successors of the ancestors who carry spiritual beliefs.

The maintenance of this belief is also manifested through various rituals and traditional ceremonies that usually appear in certain events such as; harvesting, slaughtering animals, death ceremonies, and year-ending ceremonies, which are held every 1 st of Muharram. The year-end ceremony is usually held at the balé saréséban, a building where residents believe that Prince Madrais is still alive, living there and witnessing all his followers and descendants until the end of the world. Theoretically, this is in line with Taylor's description (in Dhavamony, 1995) regarding elements of animism in local religious teachings where practices are still related to ancestral spirits.

Because their belief is not classified as a missionary religion, the traditional leaders and indigenous people of Cireundeu do not have special activities to spread their teachings. According to the elders and traditional leaders, the most important thing is to build harmony. They put forward rasa kamanusaan (humanism), which includes; welas asib (affection), undakusuk (rules), tatakrama (norms), budi bahasa (good language), budi daya and wiwaha (self-care from lust).

They said that humanity is a characteristic of indigenous people, which they believe will be a special attraction for other parties. Not the other way around, those who are busy visiting others. The interaction process like this actually reflects the practice of universalization by indigenous people because local practices have been promoted through socialization and then even become a model that other community groups can emulate.

For other issues, communal harmony is the most important thing for the indigenous people of Cireundeu. Indigenous people and the surrounding Muslim residents have been accustomed to working together 
in maintaining the environment, siskamling, and celebrating major holidays such as Indonesia's Independence Day, which is celebrated every August 17th. Likewise, the mosque does not make indigenous people the target of preaching because it focuses more on Muslim congregations as the target of their da'wa. According to one informant, this was done to avoid being debated. However, the way of life of Muslims around indigenous people has provided an understanding of the teachings of Islam itself.

The designation of the Cireundeu traditional village as a pilot model for food security is one proof of how modernization and Islamic da'wa activities can actually see this as an alternative in solving one of the social problems. Reciprocally, one form of universalization of the traditions of the indigenous people of Cireundeu has also become a model for members of other communities, even far from their environment.

\section{Continuity of the Cireundeu Tradition as an Indigenous Community} The encounter of local religions within indigenous peoples with outside traditions has always been an interesting discussion because, in general, it shows a variety of issues that are more than just superficial but also fundamental. The analysis related to parochialization and universalization is only part of the strategy shown by the indigenous people of Cireundeu in responding to the currents of modernization and Islamic da'wa activities around them. Furthermore, this also impacts the continuity and discontinuity of their traditional teaching practices in everyday life.

In general, as previously described, the indigenous people of Cireundeu consistently cultivate land only in areas that have been designated for cultivation and are very careful to cultivate land cover and avoid restricted forest areas. Here is illustrated their continuity in the norm system. Continuity and discontinuity can be observed in their choice to make cassava their main food. Consuming cassava is considered as the truth (believe), cultivating cassava instead of rice is a virtue (value), planting cassava must be in the baladahan area (norm), cassava is considered as freedom from dependence on rice (symbol). Consistency in consuming cassava has attracted the attention of the central government and the city government of Cimahi to make the Cireundeu community a model or pilot for development in food security.

The more spiritual nuances of the Cireundeu indigenous people do not have specific, routine, and sequential rituals. However, it is interesting to observe that administratively all indigenous people include Islam on their 
Kartu Tanda Penduduk (KTP, ID card) in their religious status. According to Abah Emen, this was done to facilitate the administrative process only but did not intend to practice Islam as full teaching. Therefore, at this level, it seems that the indigenous people of Cireundeu show consistency in terms of teaching (adat, customs) but not from the administrative aspect (Islam).

In addition, male indigenous people are also do not take khitan (being circumcised) like other Muslims because they are seen as hurting their bodies and are against the principle of ngamumule awak (guarding the body). In this part, they are consistent in guarding themselves from something that they believe could harm them, but at the same time, they are also administratively inconsistent. In addition, every citizen who died was buried in a customary manner, led by the elders. The corpse is put in a chest which includes rice (a return to origin), chalk (a symbol of life, the writing must be pure white), charcoal (a symbol of entering from a light place to a dark place), and clothes (a symbol of faith maintained). In the past, chests had to be made of teak wood as a symbol of "mulib ka jati mulang ka asal" (back to the Creator, which unfortunately the word "jati" actually understood literally as teak, a specific type of wood). Now it is enough with ordinary wood because teak wood is increasingly difficult to find, but it is still emitted as teak wood.

Therefore, it can be seen some of their inconsistencies with their traditional teachings, especially in the symbolic aspect; for example, Rice was included in the coffin as a provision, even though their staple food was not rice but cassava. Inconsistency can also be seen from the use of teak coffins which are then replaced with other types of wood. This shows that certain practices, especially those with a symbolic dimension, experience many discontinuities.

\section{CONCLUSION}

The indigenous peoples of Cireundeu are a social system that includes; belief system, value system, norm system, and its own symbol. The four systems face the pressure of continuity and discontinuity at the time of parochialization of the great traditions of Islam and modernity. The strength of parochialization is shown by the more adaptive attitude of the Cireundeu people towards Islamic culture at the symbolic level. This can be seen in the inclusion of Islam as a religion on their KTP. On the other hand, they can still maintain and continue their customary beliefs, values, 
and norms. As for their attitude towards the parochialization of modernity turns out to be broader, except in religion, which is just seen symbolically..

In the context of the Cimahi City community, indigenous people are a social subsystem. They can universalize in the midst of modernization and Islamic preaching that is increasingly rampant in their surroundings. Therefore, its existence is recognized as a subsystem of the Cimahi city community, which is also complete with its own belief system, values, norms, and symbols. The existence of these citizens or indigenous peoples as communities arises due to their ability to universalize in a broader cultural context. Their presence is not disturbed by the flow of modernization and other changes. Instead, they get recognition because they have succeeded in universalizing their traditions, for example, regarding food security.

\section{REFERENCES}

Achdiani, Y. (2012). Sosialisasi dan Enkulturasi Tradisi Penganut Madraisme dalam Keluarga di Kampung Cireundeu, Kota Cimahi. Universitas Padjadjaran.

Adnan, \& Solihin. (2018). Keyakinan Masyarakat Adat dan Modernisasi di Kampung Adat Masyarakat Cireundeu Kota Cimahi. Sosio-Politica, 1(8), 10-26. https://journal.uinsgd.ac.id/index.php/sociopolitica/article/view/3462.

Daeng, H. J. (2000). Manusia, Kebudayaan, dan Lingkungan: Tinjauan Antropologis. Yogyakarta: Pustaka Pelajar.

Dhavamony, M. (1995). Fenomenologi Agama. Yogyakarta: Kanisius.

Emilda, N. (2018). Nilai Karakter dalam Habituasi Budaya Masyarakat Kampung Adat Cireundeu. Jurnal Rupa, 3(1), 55-61. DOI: https://doi.org/10.25124/rupa.v3i1.1241.

Enjang. (2019). Da'wah Communication in the Sundawiwitan Community. Ilmu Dakwah: Academic Journal for Homiletic Studies, 13(1), 24-36. DOI: https://doi.org/10.15575/idajhs.v13i1.4387.

Fadhilah, A. (2014). Budaya Pangan Anak Singkong dalam Himpitan Modernisasi Pangan: Eksistensi Tradisi Kuliner Rasi (Beras Singkong) Komunitas Kampung Adat Cireundeu Leuwi Gajah Cimahi Selatan Jawa Barat. Al-Turas, 20(1), 13-30. DOI: https://doi.org/10.15408/bat.v20i1.3742.

Fatimah, A. (2014). Problematikea Tabligh di kampung Adat Cireundeu Cimahi (Studi Deskriptifpada W arga Adat Cireundeu). UIN Sunan Gunung Djati, 
Bandung.

Fitriani, H., \& Ciptandi, F. (2017). Pengolahan Kulit Umbi Singkong (Manihot Utilissima) Di Kawasan Kampung Adat Cireundeu Sebagai Bahan Baku Alternatif Perintang Warna Pada Kain. eProceedings of Art \& Design. Bandung: Telkom University.

Marriott, M. (1955). Little Communities in an Indigenous Civilization. In M. Marriott (Ed.), Village India: Studies in the Little Community. Chicago: University of Chicago Press.

Millie, J., Syarif, D., \& Fakhruroji, M. (2020). Islamic Preaching and State Regulation in Indonesia (No. 18). Melbourne. Retrieved from https://law.unimelb.edu.au/centres/cilis/research/publications/cili s-policy-papers/islamic-preaching-and-state-regulation-in-indonesia

Mulkhan, A. M. (1996). Ideologisasi Gerakan Dakwah: Episod Kehidupan M

Natsir dan Azhar Basyir. Yogyakarta: SIPress.

Mulyani, A., \& Wirakusuma, R. M. (2016). Perencanaan Paket Wisata Berdasarkan Karakteristik dan Motivasi Wisatawan yang Datang ke Kampung Cireundeu Kota Cimahi. Jurnal Manajemen Resort Dan Leisure, 13(2), 1-14.

Nurhayanto, P., Wildan, D., \& Alia, M. N. (2016). Transformasi Nilai-nilai Kearifan Lokal Masyarakat Adat Cireundeu. Societas: Jurnal Pendidikan Sosiologi, 6(1). DOI: https://doi.org/10.17509/sosietas.v6i1.2872.

Nurrohman, F., \& Suhendi, H. (2019). Peluang, Tantangan, dan Strategi Dakwah di Kampung Adat Cireundeu Kelurahan Leuwi Gajah Kecamatan Cimabi Selatan. Bandung.

Purwasih, T., Filia, R. A., \& Sobari, T. (2019). Loyalitas Masyarakat Kampung Adat Cireundeu dalam Memepertahankan Bahasa Ibu. PAROLE (Jurnal Pendidikan Bahasa Dan Sastra Indonesia), 2(2), 239_ 242. DOI: http://dx.doi.org/10.22460/p.v2i2p\%25p.2692.

Putranto, K., \& Taofik, A. (2014). Pola Diversifikasi Konsumsi Pangan Masyarakat Adat Kampung Cireundeu Kota Cimahi Jawa Barat. Jurnal Istek, $8(1)$ 159-181. https://journal.uinsgd.ac.id/index.php/istek/article/view/215.

Ramadhan, A. (2016). Disfungsional Peran Karang Taruna dalam Pelestarian Kearifan Lokal di Kampung Cireundeu. Societas: Jurnal Pendidikan Sosiologi, 6(2). DOI: https://doi.org/10.17509/sosietas.v1i1.4107.

Sambas, S. (1995). Konstruksi Keilmuan Dakwah Islam Prespektif Filsafat Ilmu: Upaya Memahami dan Sosialisasi Pemberlakuan Kurikulum Nasional 
Fakultas Dakwah Tahun 1994. Bandung: Fakultas Dakwah IAIN Sunan Gunung Djati Bandung.

Stewart, C. (1991). Demons and the Devil: Moral Imagination in Modern Greek Culture. Princeton: Princeton University Press.

Sumiati, E. (2016). Model Pemberdayaan Masyarakat dalam Mempertahankan Kearifan Lokal (Etnografi Pada Masyarakat Adat Kampung Cireundeu Kota Cimahi). Damar Jayagiri, 1(8), 1-10.

Tambiah, S. (1970). Buddhism and the Spirit Cults in NorthEast Thailand. Cambridge: Cambridge University Press.

Taum, Y. Y. (1998). Tradisi Nololo dalam Masyarakat Fataluku Kabupaten Lautem Propinsi Timor Timur: Suatu Studi tentang Kepercayaan Lokal Melalui Khazanah sastra Lisan.

Tramontane, P. M. (2017). Tinjauan Konsistensi Masyarakat Kampung Adat Cireundeu Dalam Melestarikan Adat Istiadat Leluhur. Ultimart: Jurnal Komunikasi Visual, 10(2), 12-23. DOI: https://doi.org/10.31937/ultimart.v10i2.769. 